\title{
Responses of Algal Cells to Engineered Nanoparticles Measured as Algal Cell Population, Chlorophyll a, and Lipid Peroxidation: Effect of Particle Size and Type
}

\author{
D. M. Metzler, ${ }^{1}$ A. Erdem, ${ }^{2}$ Y. H. Tseng, ${ }^{3}$ and C. P. Huang ${ }^{1}$ \\ ${ }^{1}$ Department of Civil and Environmental Engineering, University of Delware, Newark, DE 19716, USA \\ ${ }^{2}$ Department of Environmental Engineering, Akdeniz University, Akdeniz 07058, Turkey \\ ${ }^{3}$ Department of Chemical Engineering, National Taiwan University of Science and Technology, Taipei 106, Taiwan
}

Correspondence should be addressed to C. P. Huang, huang@udel.edu

Received 15 May 2012; Accepted 24 July 2012

Academic Editor: Mallikarjuna Nadagouda

Copyright () 2012 D. M. Metzler et al. This is an open access article distributed under the Creative Commons Attribution License, which permits unrestricted use, distribution, and reproduction in any medium, provided the original work is properly cited.

\begin{abstract}
This paper investigated toxicity of three engineered nanoparticles (ENP), namely, $\mathrm{Al}_{2} \mathrm{O}_{3}, \mathrm{SiO}_{2}$, and $\mathrm{TiO}_{2}$ to the unicellular green algae, exemplified by Pseudokirchneriella subcapitata with an emphasis on particle size. The changes in $\mathrm{pH}$, cell counts, chlorophyll a, and lipid peroxidation were used to measure the responses of the algal species to ENP. The most toxic particle size was TiO ${ }_{2}$ at $42 \mathrm{~nm}$ with an EC20 of $5.2 \mathrm{mg} / \mathrm{L}$ and $\mathrm{Al}_{2} \mathrm{O}_{3}$ at $14-18 \mathrm{~nm}$ with an EC20 of $5.1 \mathrm{mg} / \mathrm{L}$. $\mathrm{SiO}_{2}$ was the least toxic with an EC20 of $318 \mathrm{mg} / \mathrm{L}$. Toxicity was positively related to the surface charge of both ENP and algae. The chlorophyll content of the algal cells was influenced by the presence of ENP, which resulted in limited light and availability of nutrients due to increase in turbidity and nutrient adsorption onto the ENP surface, separately. Lipid peroxidation was attributed to reactive oxygen species (ROS). Fast reaction between algal cells and $\mathrm{ROS}$ due to direct contact between $\mathrm{TiO}_{2}$ and algal cells is an important factor for lipid peroxidation.
\end{abstract}

\section{Introduction}

Nanomaterials have been used in industrial applications and commercial products at a rapid pace. New types of NM are being developed every day. These new materials can be more hazardous than their bulk states due to not only small size but also numeral novel properties. Among these particles, $\mathrm{TiO}_{2}$, $\mathrm{SiO}_{2}$, and $\mathrm{Al}_{2} \mathrm{O}_{3}$ have been shown to have adverse effects on the pulmonary systems $[1-3]$. There have been a few studies on the effect of these particles on algae. Van Hoecke et al. [4] observed changes in the growth rate of $P$. subcapitata when exposed to $\mathrm{SiO}_{2}$. Warheit et al. [5] reported growth inhibition of P. subcapitata with a 72-hour EC50 of 87 and $61 \mathrm{mg} / \mathrm{L}$ for $\mathrm{TiO}_{2}$ at size of 38.5 and $100 \mathrm{~nm}$, respectively. Ji et al. [6] reported a 6-day survival EC50 of $120 \mathrm{mg} / \mathrm{L}$ for anatase with a size of $20-50 \mathrm{~nm}$. Literature results so far have indicated a clear dose-response relationship between microbial survival and ENP concentration. However, more studies are needed to illustrate the mechanisms of microbial responses to ENP.
Reactive oxygen species (ROS) are generated in the thylakoid membrane during photosynthesis [7]. Hydrogen peroxide has been suggested to be the dominant species of ROS in algae. This is due to relatively long reaction time involving hydrogen peroxides, approximately 1 millisecond compared to nanoseconds of other ROS species. The ROS-protective mechanisms of algae include superoxide dismutase, ascorbate peroxidase, catalase, and glutathione peroxidase [7]. The photoactivity of $\mathrm{TiO}_{2}$ also generates ROS. The generation of ROS has also been linked to particle size, crystalline structure, and surface defects [8]. The particle size is an important variable in that as the specific surface area increases reversely proportionally to particle diameter. The increase in specific surface area will result in the increase in specific quantum yield of photocatalytic particles thus increasing the ROS generation [9-11]. Bakardjieva et al. [10] demonstrated that as the specific surface area of $\mathrm{TiO}_{2}$ increased, 4-chlorophenol degradation increased. Tesng et al. [9] indicated that 2-chlorophenol degradation decreased with increased primary particle size. The size effect on photoctalytic capacity has been 
seen in other particles including CdS [12], HgSe and PbSe [13], $\mathrm{ZnO}$ [14], and $\mathrm{SnO}_{2}$ [15]. It was concluded that particle size of quantum dots is one major factor affecting cytotoxicity [16]. Kashiwada [17] demonstrated that latex nanoparticle was adsorbed to spawned ST II eggs at an optimum particle size of $474 \mathrm{~nm}$. Adams et al. [18] examined the effect of particle size of $\mathrm{TiO}_{2}, \mathrm{SnO}_{2}$, and $\mathrm{ZnO}$ on $B$. subtilis and E. coli and observed some degree of toxicity whether the particles were under light or not. However, they were unable to draw conclusion about the particle size effect due to the change of particle size once in suspension.

The objective of this study was to determine the toxicity of photocatalytic (e.g., $\mathrm{TiO}_{2}$ ) and non-photocatalytic nanoparticles (e.g., $\mathrm{Al}_{2} \mathrm{O}_{3}$ and $\mathrm{SiO}_{2}$ ) over a wide range of particle size by evaluating the effects on cell population, chlorophyll, and lipid peroxidation on P. subcapitata. The mode of toxicity was also examined.

\section{Methods and Materials}

2.1. Nanoparticles. Stock suspensions of $2 \mathrm{~g} / \mathrm{L}$ were made with aluminum oxide, silica dioxide, or titanium dioxide in $150-500 \mathrm{~mL}$ of Erlenmeyer flask with algal growth medium [19]. Table 1 gives the information about the physical and chemical properties of ENP materials studied. The stock suspensions were autoclaved for 20 minutes at $120^{\circ} \mathrm{C}$ at least one day prior to experiment and stored at room temperature until use.

2.2. Algal Culture. Algal culture, P. subcapitata, was purchased from Aquatic Biosystems (Fort Collins, CO). The algal inoculums were stored at $4^{\circ} \mathrm{C}$ in the dark for no longer than 6 months. Culturing of the algae in $3 \mathrm{~L}$ continually stirred tank reactor (CSTR) followed that of Metzler [20]. Hydraulic residence time (HRT) of the CSTR was 3 days, with a flow rate of $50 \mathrm{~mL} / \mathrm{h}$.

2.3. Growth Chambers. Growth chambers were approximately $80 \mathrm{~cm} \times 62 \mathrm{~cm} \times 68 \mathrm{~cm}$, wood or metal frame that was covered in black cloth. A bank of 6 fluorescent lights was suspended overhead on the frame. Lights used included model GE PL/AQ F12T20 (General Electric, Fairfield, CT), Gro-lux F12T20/Gro/AQ, and 2 Sylvania Gro-lux wide spectrum F12T20/Gro/AQ/WS (Rutherford, NJ, USA). These light fixtures supplied an average lux of $1632 \pm 157$, measured from the top of the test beakers. A muffin fan or centrifugal miniblower removed excess heat generated by the lights. Each fan or blower used was suspended on the outside of the chamber approximately 1 inch below the lights, with an access port cut into the cloth. An orbital platform shaker held the beakers and was set to oscillate at $150 \mathrm{rpm}$.

2.4. Exposure Experiments. Aliquots of stock NP were added to a series of $1 \mathrm{~L}$ beakers. Stock suspensions were continuously stirred with a magnetic stirring bar during this time. Algal growth medium was then added to the beakers to bring the volume to $100 \mathrm{~mL}$. The suspensions were sonicated for 2 minutes at a power level of $48 \mathrm{~W}$ using a Cole-Palmer 4710 series ultrasonic homogenizer. The suspensions were then allowed to equilibrate for one hour. After one hour, $100 \mathrm{~mL}$ of the CSTR algal culture was added to the NP suspension to achieve an algal cell density of $1.4 \pm 0.9 \times 10^{6} \mathrm{cell} / \mathrm{mL}$. The samples were then placed in one of three growth chambers. The duration of the exposure test was 4 days.

Each day during the course of exposure experiment the sample $\mathrm{pH}$ was measured with a Corning $\mathrm{pH} / \mathrm{ion}$ analyzer 350 equipped with a Corning semimicro combo $\mathrm{pH}$ probe. Additionally, the minimum and the maximum temperatures of the growth chambers were recorded for each 24-hour time period. At the end of the 4-day exposure, the sample volume remaining was determined by measuring the difference in volume before and after exposure runs. Forty milliliters of sample were collected in $50 \mathrm{~mL}$ Fisherbrand centrifuge tubes which were analyzed for chlorophyll a. Additionally, $12 \mathrm{~mL}$ were collected in $15 \mathrm{~mL}$ Fisherbrand centrifuge tubes and analyzed for cell density and lipid peroxidation. The samples were stored at $4^{\circ} \mathrm{C}$ in the dark (a maximum of 7 days) until analyzed. According to Weber et al. [21], no changes in chlorophyll content should occur of this time period.

Cell densities were measured by direct cell counts. One milliliter of sample was diluted in $1 \mathrm{~mL}$ of $0.5 \mathrm{M}$ lauryl sulfate. This was then mixed on a Dade vortex shaker model S8223-1 for 2 minutes. An aliquot of sample was then added to a hemocytometer for counting on an Olympus AX70 microscope; samples were counted a minimum of 4 times. Cell densities were converted into total cell population by multiplying the cell counts by the volume of sample remaining in the $1 \mathrm{~L}$ test beakers at the end of the test duration. The total cell populations were then corrected for the initial population and normalized based on the control, using the following equation:

$$
R_{s}=\frac{(\rho \times v)_{t}}{(\rho \times v)_{c}}
$$

where $R_{s}$ is the normalized growth, $\rho$ is the cell density $($ cell $/ \mathrm{mL}), v$ is the volume of sample at the end of the 4day exposure period $(\mathrm{mL}), t$ is the duration a sample was exposed to a specific ENP, and $c$ is the control sample with no treatment.

For the determination of chlorophyll a, the samples were concentrated to between $0.5-3 \mathrm{~mL}$, and then analyzed according to Standard Methods for the Examination of water and Wastewater [22]. In brief, the concentrated samples were added to glass homogenization tubes. The $50 \mathrm{~mL}$ sample tubes were rinsed with a few milliliters of $\mathrm{Mg}$ acetone $(2.0 \mathrm{~g}$ of $\left(\mathrm{MgCO}_{3}\right)_{4}$ and $\mathrm{Mg}(\mathrm{OH})_{2} \cdot 5 \mathrm{H}_{2} \mathrm{O}$ diluted to $200 \mathrm{~mL}$ in distilled deionized water then diluted $1: 10$ in acetone). The volume in the homogenization tube was brought to $3 \mathrm{~mL}$ with $\mathrm{Mg}$-acetone solution. The samples were then homogenized for 1 minute at $2000 \mathrm{rpm}$ with a Glas-Col variable speedreversible homogenizer. The samples were then steeped at $4^{\circ} \mathrm{C}$ in the dark for 2 hours in $15 \mathrm{~mL}$ plastic centrifuge tubes. After the steep time, the samples were centrifuged for 30 minutes at $664 \times \mathrm{g}$. The optical density of the supernatant was measured at 750 and $664 \mathrm{~nm}$, respectively, on a HewlettPackard UV-Vis model $8525 \mathrm{~A}$. $\mathrm{HCl}(0.1 \mathrm{~mL}$ of $0.1 \mathrm{~N})$ were added to the samples and the optical density was measured 





again at 750 and $665 \mathrm{~nm}$ after 90 seconds of equilibration. The concentration of chlorophyll a ([Chla] in $\mathrm{mg}-\mathrm{Chla} / \mathrm{m}^{3}$ ) was calculated by the following equation:

$$
[\text { Chla }]=26.7\left(A_{664}-A_{665}\right) \times V_{1} \times\left(V_{2} \times l\right)^{-1},
$$

where $A_{665}$ is the absorbance at $664 \mathrm{~nm}$ before adding acid, $A_{665}$ is the absorbance at $665 \mathrm{~nm}$ after adding acid, $V_{1}$ is the volume of extract (L), $V_{2}$ is the sample volume $\left(\mathrm{m}^{3}\right)$, and $l$ optical path $(\mathrm{cm})$. The specific chlorophyll a was calculated by the following expression:

$$
y=[\text { Chla }] \times \rho^{-1} \times 10^{-6},
$$

where $y$ is the specific chlorophyll a (mg Chla/cell), [Chla] is the concentration of chlorophyll a $\left(\mathrm{mg} \mathrm{Chla} / \mathrm{m}^{3}\right)$, and $\rho$ is the cell density (no. cell/mL). The specific chlorophyll a, $y$, was then normalized with respect to the control according to the following equation:

$$
Y=y \times y_{c}^{-1}
$$

where $Y$ is the normalized specific chlorophyll a (dimensionless), $y$ is the specific chlorophyll a (mg Chla/cell), and $y_{c}$ is the specific chlorophyll a of the control (mg Chla/cell).

Finally, analysis of sample for lipid peroxidation followed the method in Maness et al. [23]. In brief, $1 \mathrm{~mL}$ of sample was added to $2 \mathrm{~mL}$ of $10 \%$ trichloroacetic acid. The samples were then centrifuged for 45 minutes at $11000 \times \mathrm{g}$. The supernatant was then added to $3 \mathrm{~mL}$ of $6.7 \mathrm{~g} / \mathrm{L}$ 2-thiobarbituric acid, which was previously heated to $60^{\circ} \mathrm{C}$ in order to dissolve the solid. The samples were then heated in boiling water for 10 minutes. After cooling, the absorbance of samples was measured on a Hewlett-Packard UV-Vis model 8525A at 532 and $600 \mathrm{~nm}$ wavelengths, respectively. The absorbance at $532 \mathrm{~nm}$ was corrected for the background at $600 \mathrm{~nm}$. Calibration standards were made from 1,1,3,3-tetramethoxypropane. The specific lipid peroxidation $(z)$ was calculated by the following equation:

$$
z=[\mathrm{MDA}] \times v \times(\rho \times v)^{-1} \times 10^{-3},
$$

where $z$ has the unit of pmol MDA/cell, [MDA] is the concentration of malondialdehyde-thiobarbituric acid complex measured $(\mu \mathrm{M}), \nu$ is the volume of sample at the end of the 4 day exposure $(\mathrm{mL})$, and $\rho$ is the cell density (no. cell $/ \mathrm{mL}$ ). The $z$ value was then normalized against the control according to the following equation:

$$
Z=z \times z_{c}^{-1},
$$

where $Z$ is relative lipid peroxidation (dimensionless), $z$ is the specific lipid peroxidation of the sample (pmol MDA/cell), and $z_{c}$ is the specific lipid peroxidation of the control (pmol $\mathrm{MDA} / \mathrm{cell})$.

Dose-response curves were used to calculate the effective concentration (EC). The USEPA [19] uses daily cell density to calculate the growth inhibition concentration (IC). The number of samples to be processed per day made this impractical. Lethal concentration (LC) values, defined as the

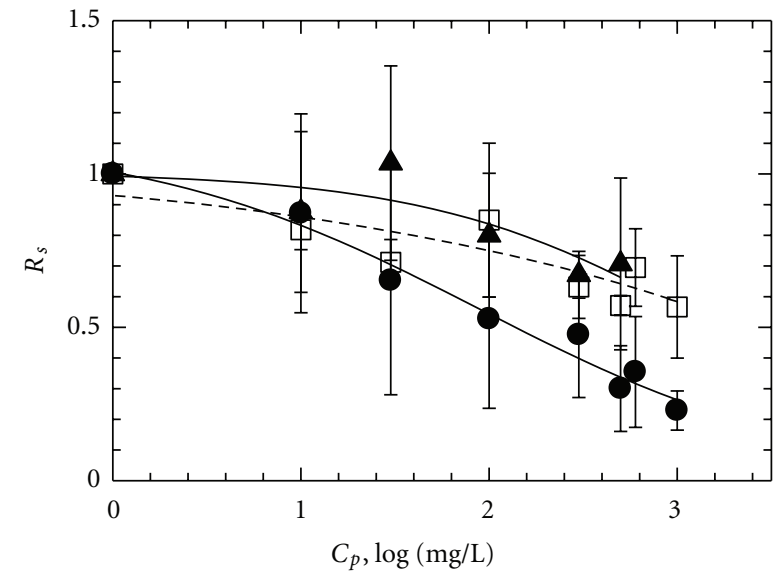

Figure 1: Normalized specific four-day growth $\left(R_{s}\right)$ dose-response curve. Solid circles are $\mathrm{Al}_{2} \mathrm{O}_{3}(17.6 \mathrm{~nm})$. Open squares are $\mathrm{SiO}_{2}$ $(14.3 \mathrm{~nm})$. Solid triangles are $\mathrm{TiO}_{2}(18.7 \mathrm{~nm})$. Error bars are \pm 1 standard deviation $(n \geq 3)$. Lines represent four-parameter logistic curves fitted to the data in SigmaPlot ver. 9.01. Experimental conditions: initial algae concentration $=1.4 \pm 0.9 \times 10^{6} \mathrm{cell} / \mathrm{mL}$, test duration $=4$ days, and initial test volume $=200 \mathrm{~mL}$.

total number of organisms that died during exposure, were not used to determine the toxicity of NP to algae. Therefore, EC was chosen. EC value is defined as the difference in total growth between control and test sample. EC20 and EC50 are concentrations that limit growth to 20 and $50 \%$ of the control samples.

\section{Results}

The size and type are important attributes of ENP. The major objective of the present research was to determine how particle size and type will affect the physiology and biochemical behavior of algae exemplified by $P$. subcapitata. The algal cells were exposed to $\mathrm{TiO}_{2}, \mathrm{Al}_{2} \mathrm{O}_{3}$, and $\mathrm{SiO}_{2}$ for $96 \mathrm{~h}$ at various size classes and concentrations. During the time of exposure, the average temperature was $23.0 \pm 1.2^{\circ} \mathrm{C}$ and the average $\mathrm{pH}$ was $7.6 \pm 0.4$.

3.1. Effect of Particle Concentration. In order to determine the effect of NP concentration on P. subcapitata, $\mathrm{Al}_{2} \mathrm{O}_{3}$ $(17.6 \mathrm{~nm}), \mathrm{SiO}_{2}(14.3 \mathrm{~nm})$, and $\mathrm{TiO}_{2}(18.7 \mathrm{~nm})$ were selected due to their similarity in size. Figure 1 shows the doseresponse curves of $\mathrm{Al}_{2} \mathrm{O}_{3}, \mathrm{SiO}_{2}$, and $\mathrm{TiO}_{2}$ in terms of normalized specific growth $\left(R_{S}\right)$. In all cases, as concentration increased from 0 to $1000 \mathrm{mg} / \mathrm{L}$, the $R_{s}$ decreased. EC20 values were calculated using SigmaPlot version 9.01 as follows: $\mathrm{Al}_{2} \mathrm{O}_{3}(17.6 \mathrm{~nm})=5.14 \mathrm{mg} / \mathrm{L}, \mathrm{TiO}_{2}(18.7 \mathrm{~nm})=129 \mathrm{mg} / \mathrm{L}$, and $\mathrm{SiO}_{2}(14.3 \mathrm{~nm})=318 \mathrm{mg} / \mathrm{L}$.

Chlorophyll content of algae can be used as a measurement of physiological health [22]. In order to determine if $\mathrm{NP}$ was stressing the algae, chlorophyll a measurements were conducted. Figure 2 shows chlorophyll a content plotted against the concentrations of the respective NP. It can be seen that there was a slight increase in the chlorophyll content as the $\mathrm{Al}_{2} \mathrm{O}_{3}$ concentration was increased to about $10 \mathrm{mg} / \mathrm{L}$. 


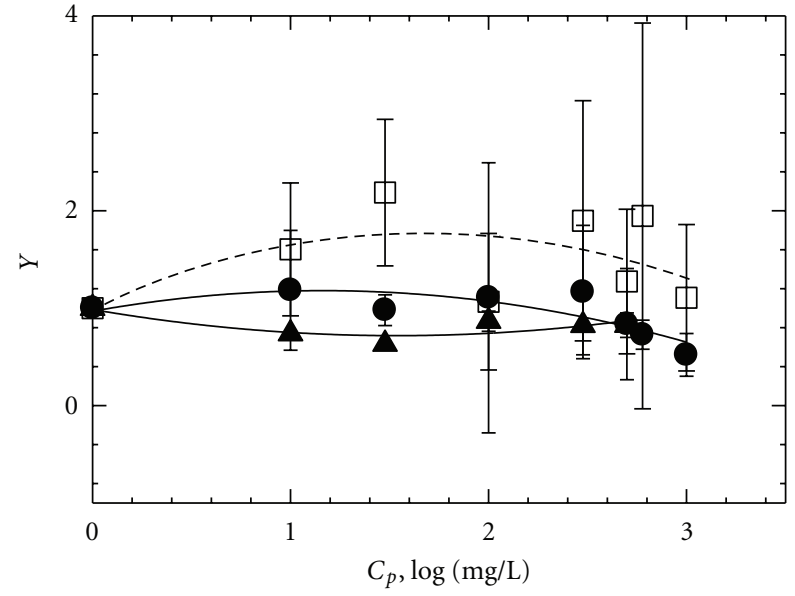

Figure 2: Normalized specific chlorophyll a $(Y)$ as a function of the concentration of the NP. Solid circles are $\mathrm{Al}_{2} \mathrm{O}_{3}(17.6 \mathrm{~nm})$. Open squares are $\mathrm{SiO}_{2}(14.3 \mathrm{~nm})$. Solid triangles are $\mathrm{TiO}_{2}(18.7 \mathrm{~nm})$. Error bars are \pm 1 standard deviation $(n \geq 3)$. Lines are 2 nd-order polynomial fits to the data. The data was fitted with an empirical 2nd-order polynomial from SigmaPlot ver. 9.01. Experimental conditions: initial algae concentration $=1.4 \pm 0.9 \times 10^{6} \mathrm{cell} / \mathrm{mL}$, test duration $=4$ days, and initial test volume $=200 \mathrm{~mL}$.

As the $\mathrm{Al}_{2} \mathrm{O}_{3}$ (solid circles) concentration was increased above $10 \mathrm{mg} / \mathrm{L}$, the chlorophyll content decreased to approximately $50 \%$ of the control at $1000 \mathrm{mg} / \mathrm{L}$ of $\mathrm{Al}_{2} \mathrm{O}_{3}$. As $\mathrm{SiO}_{2}$ (open squares) concentration was increased from 0 to $30 \mathrm{mg} / \mathrm{L}$, the Chla increased from 1 to 2.2 . The Chla then decreased to 1 at $1000 \mathrm{mg} / \mathrm{L}$ of $\mathrm{SiO}_{2}$. The $\mathrm{NP}$ of $\mathrm{TiO}_{2}$ (solid triangles) had the inverse effect of $\mathrm{Al}_{2} \mathrm{O}_{3}$ and $\mathrm{SiO}_{2}$. The Chla decreased from 1 to 0.63 when $\mathrm{TiO}_{2}$ concentration was increased from 0 to $30 \mathrm{mg} / \mathrm{L}$. At $\mathrm{TiO}_{2}$ concentration greater than $30 \mathrm{mg} / \mathrm{L}$ the Chla increased to 0.83 at $1000 \mathrm{mg} / \mathrm{L}$.

Figure 3 shows the normalized specific MDA, $Z$, as a function of ENP concentration for $\mathrm{SiO}_{2}$ (open squares), $\mathrm{Al}_{2} \mathrm{O}_{3}$ (solid circles), and $\mathrm{TiO}_{2}$ (solid triangles). The normalized specific MDA increased with the log concentration of $\mathrm{SiO}_{2}$. The maximum normalized specific MDA, $3.1 \pm 1.3$, occurred at $500 \mathrm{mg} / \mathrm{L}$ of $\mathrm{SiO}_{2}$. However, the $\mathrm{SiO}_{2}$ results are not significantly different $(\alpha=0.05)$ from those of $\mathrm{TiO}_{2}$ and $\mathrm{Al}_{2} \mathrm{O}_{3}$ due to large standard deviations in the data. Error bars were not shown in Figure 3 for $\mathrm{SiO}_{2}$ due to large values. $\mathrm{Al}_{2} \mathrm{O}_{3}$ caused an increased normalized specific MDA only at concentration $>100 \mathrm{mg} / \mathrm{L}$. The maximum normalized specific MDA was $2.8 \pm 2.7$ at $1000 \mathrm{mg} / \mathrm{L}$ of $\mathrm{Al}_{2} \mathrm{O}_{3}$. For $\mathrm{TiO}_{2}$ (Figure 3) normalized specific MDA decreased from 1 to 0.61 when the $\mathrm{TiO}_{2}$ concentration was increased from 0 to $30 \mathrm{mg} / \mathrm{L}$, respectively. At concentrations greater than $30 \mathrm{mg} / \mathrm{L}$, the normalized specific lipid peroxidation increased until a maximum of $1.8 \pm 1.4$ at $600 \mathrm{mg} / \mathrm{L}$ was reached for $\mathrm{TiO}_{2}$. The increase in normalized specific MDA was most likely due to photocatalytic properties of the $\mathrm{TiO}_{2}$.

3.2. Particle Size Effect. In order to determine how particle size affects the toxicity of titanium dioxide, algae was exposed to $\mathrm{TiO}_{2}$ at particle size in the range between 5.3 and $204 \mathrm{~nm}$.

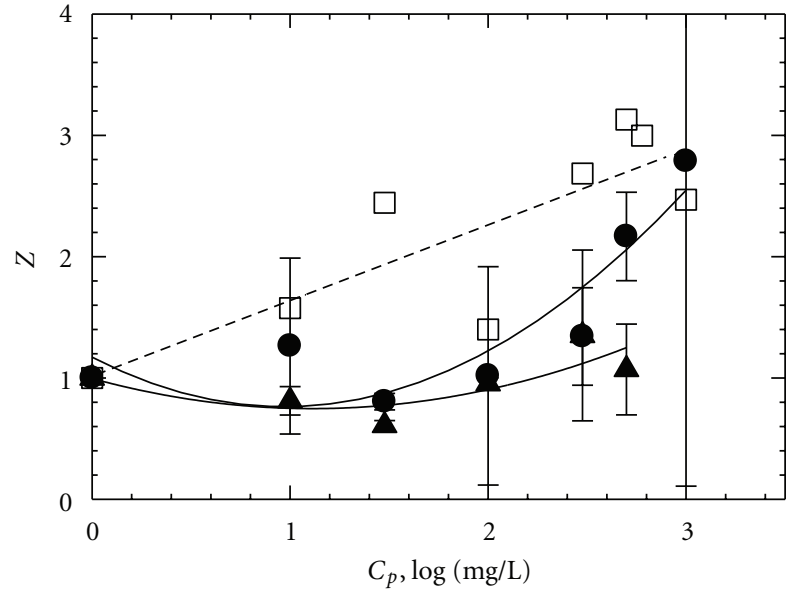

FIGURE 3: Normalized specific lipid oxidation $(Z)$ as a function of the concentration NP. Solid circles are $\mathrm{Al}_{2} \mathrm{O}_{3}$ (17.6 nm). Open squares are $\mathrm{SiO}_{2}(14.3 \mathrm{~nm})$. Solid triangles are $\mathrm{TiO}_{2}(18.7 \mathrm{~nm})$. Error bars are \pm 1 standard deviation. Error bars were omitted from $\mathrm{SiO}_{2}$ plot. Lines are 2nd-order polynomial fits to the data. Experimental conditions: initial algae concentration $=1.4 \pm 0.9 \times$ $10^{6} \mathrm{cell} / \mathrm{mL}$, test duration $=4$ days, and initial test volume $=200 \mathrm{~mL}$.

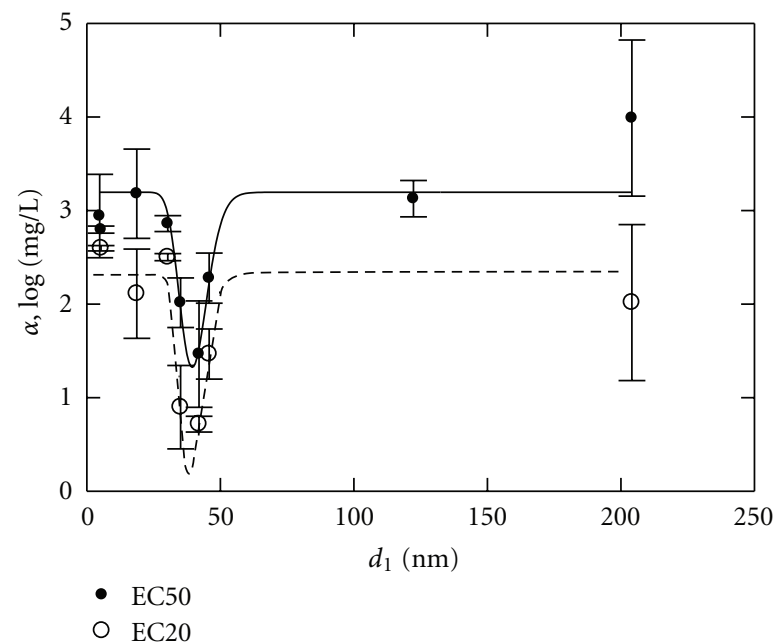

FIGURE 4: Critical specific growth $(\alpha)$ as a function of primary particle size of $\mathrm{TiO}_{2}$ in terms of EC20 and EC50. Lines are a five-parameter modified log normal empirical fitting (7) from SigmaPlot ver. 9.01 for EC20 (dotted) and EC50 (solid). Error bars are \pm 1 standard deviation. Experimental conditions: initial algae concentration $=1.4 \pm 0.9 \times 10^{6} \mathrm{cell} / \mathrm{mL}$, test duration $=4$ days, and initial test volume $=200 \mathrm{~mL}$.

EC20 and EC50 were calculated with Toxicity Relationship Analysis Program ver. 1 (TRAP) [24] using the logistic equation. Figure 4 gives the EC20 and EC50 values as a function of the primary NP size $\left(d_{1}\right)$ exemplified by $\mathrm{TiO}_{2}$. As the ENP size increased from 5.3 to $41 \mathrm{~nm}$ both, EC20 and EC50 decreased. A minimum EC20 of $5.2 \mathrm{mg} / \mathrm{L}$ and a minimum EC50 of $25.5 \mathrm{mg} / \mathrm{L}$ were observed at $42 \mathrm{~nm}$ primary particle size. The EC50 and EC20 then increased at $d_{1}>42 \mathrm{~nm}$. Warheit et al. reported 72-h growth EC50 


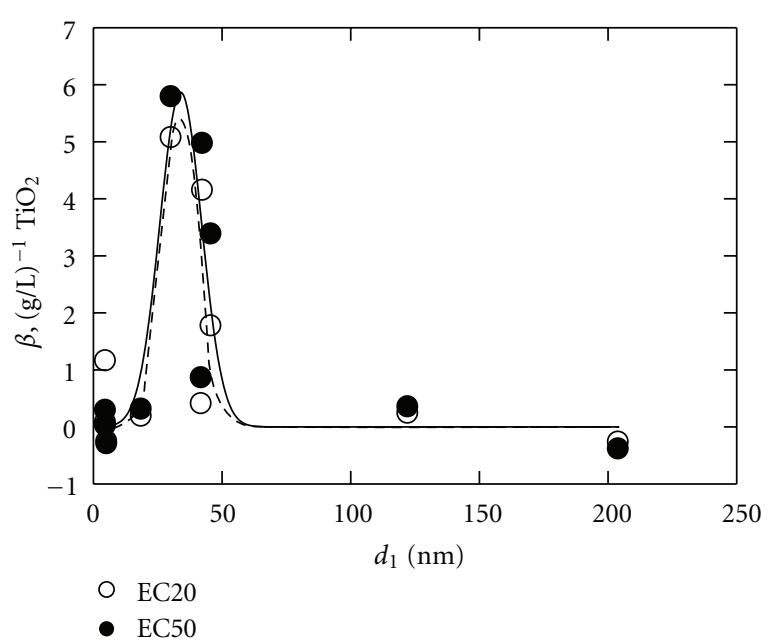

FIgURe 5: Critical specific chlorophyll a content $(\beta)$ as a function of primary particle size of $\mathrm{TiO}_{2}$ in terms of EC20 and EC50. Lines are fitted 3-parameter Gaussian equation (7) in SigmaPlot ver. 9.01 for EC20 (dotted) and EC50 (solid). Experimental conditions: initial algae concentration $=1.4 \pm 0.9 \times 10^{6} \mathrm{cell} / \mathrm{mL}$, test duration $=4$ days, and initial test volume $=200 \mathrm{~mL}$.

of 87 and $61 \mathrm{mg} / \mathrm{L}$ for $d_{1}$ of 38.5 and $100 \mathrm{~nm}$, respectively [5]. Gonclaves et al. reported EC50 values varied between $241 \mathrm{mg} / \mathrm{L}$ and $71.1 \mathrm{mg} / \mathrm{L}$ for $\mathrm{TiO}_{2}$ sized between 10 and $300 \mathrm{~nm}$ [25]. As the primary particle size increased to $204 \mathrm{~nm}$ the EC50 and EC20 increased to 9761.3 and $103.7 \mathrm{mg} / \mathrm{L}$, respectively. The results were fitted with an empirical fourparameter log-normal equation:

$$
\alpha=d_{1}^{1}+a^{\prime} \exp \left\{-0.5\left[\frac{\ln \left(d_{1} / d_{1}^{2}\right)}{b^{\prime}}\right]^{2}\right\},
$$

where $\alpha$ is the effect concentration at either 20 or $50 \%, a^{\prime}$ is a fitted constant, $b$ is the concentration of the most toxic ENP size, $d_{1}(\mathrm{~nm})$ is the initial diameter of the NP, $d_{1}^{1}$ is the smallest $d_{1}(\mathrm{~nm})$, and $d_{1}^{2}$ is the $d_{1}$ in which the minimum EC50 or EC20 occurs. The $r^{2}$ values of these regressions were 0.80 and 0.90 for EC50 and EC20, respectively. Within the range of 30 to $60 \mathrm{~nm}$, EC values decreased. The average minimum EC value occurred at $39.3 \pm 0.2 \mathrm{~nm}$ for $\mathrm{TiO}_{2}$. The calculated minimum EC values were $1.5 \mathrm{mg} / \mathrm{L}$ for EC20 and $21 \mathrm{mg} / \mathrm{L}$ for EC50.

Figure 5 shows the effect of $d_{1}$ of nano- $\mathrm{TiO}_{2}$ on the chlorophyll a content of the algal cells. The ordinate $(\beta)$ is the slope of the Chla at the EC20 and EC50 for $\mathrm{TiO}_{2}$ or the critical specific chlorophyll (CSC) at EC20 or EC50, that is, $\beta_{20}$ and $\beta_{50}$, respectively. A positive $\beta_{20}$ indicates increase in chla production per mass of $\mathrm{TiO}_{2}$ at EC20 compared to the control sample; a negative value implies the opposite. As the particle size increased from 4.8 to $30.3 \mathrm{~nm}$, the $\beta_{20}$ and $\beta_{50}$ increased from about 0 to $5.5 \mathrm{~L} / \mathrm{g} \mathrm{TiO}$. The $\beta_{x}$ reached a maximum value at $30.3 \mathrm{~nm}$, then abruptly decreased as the primary particle size increased. At NP size between 4.8 and $18.7 \mathrm{~nm}$, there was little difference between the control and exposure. Results clearly showed that over the primary particle size range studied, for example, $19 \sim 50 \mathrm{~nm}$, the Chla

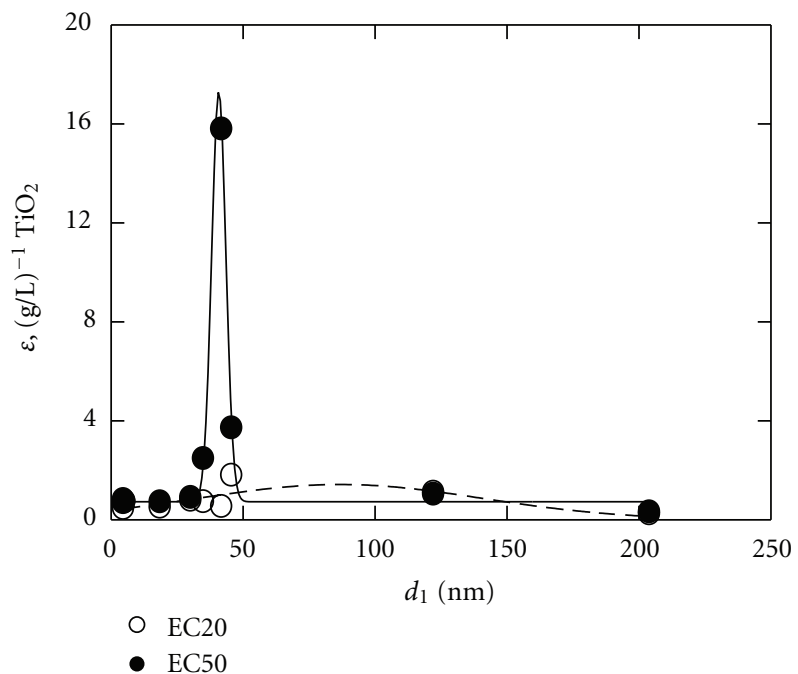

FIGURE 6: Critical specific lipid peroxidation $(\varepsilon)$ as a function of primary particle size in terms of EC20 and EC50. Line is fitted 3parameter Gaussian equation (8) in SigmaPlot ver. 9.01 for EC20 (dotted) and EC50 (solid). Experimental conditions: initial algae concentration $=1.4 \pm 0.9 \times 10^{6} \mathrm{cell} / \mathrm{mL}$, test duration $=4$ days, and initial test volume $=200 \mathrm{~mL}$.

production increased at EC20 and EC50. When the primary particle size was greater than ca. $150 \mathrm{~nm}$, the $\beta_{20}$ and $\beta_{50}$ became negative, indicating a decrease in Chla. The data was empirically fitted to a three-parameter Gaussian equation (8) using SigmaPlot version 9.01, that is,

$$
\beta=a^{\prime \prime} \exp \left\{-0.5\left[\frac{\left(d_{1}-d_{1}^{3}\right)}{b^{\prime \prime}}\right]^{2}\right\} .
$$

The variables in (8) are as follows: $a$ and $b$ are fitting parameters, $d_{1}$ is the ENP size $(\mathrm{nm})$, and $d_{1}^{3}$ is the NP size $(\mathrm{nm})$ with the largest $\beta$. Fitting the data to (8) resulted in a chlorophyll production maximum at $33 \mathrm{~nm}$ of $\mathrm{TiO}_{2}$. The maximum $\beta$ values were 5.4 and 5.9 times the control for $\beta_{20}$ and $\beta_{50}$, respectively. The model fitted the data well with an $r^{2}$ value of 0.69 and 0.73 for EC20 and EC50 data, respectively.

Figure 6 shows the effect of $d_{1}$ on the lipid peroxidation. The slope of the $Z$ plotted against $\mathrm{TiO}_{2}$ concentration at the EC20 and EC50 of $\mathrm{TiO}_{2}$ was obtained. This value is the critical specific lipid peroxidation $\left(\varepsilon_{x}\right)$ where $x$ is the EC20 or EC50. Here $\varepsilon_{20}$ and $\varepsilon_{50}$ were plotted as a function of $d_{1}$. As he ENP size increased from 4.8 to $30 \mathrm{~nm}$, there was little change in the $\varepsilon_{20}$ with values between $0.54 \pm 0.14 \mathrm{~L} / \mathrm{g} \mathrm{TiO}$. The $\varepsilon_{20}$ then increased to $1.78 \mathrm{~L} / \mathrm{g} \mathrm{TiO}{ }_{2}$ at $d_{1}$ of $45.8 \mathrm{~nm}$. The $\varepsilon_{20}$ then decreased to $0.22 \mathrm{~L} / \mathrm{g} \mathrm{TiO}_{2}$ at $d_{1}$ of $204.1 \mathrm{~nm}$. The $\varepsilon_{50}$ data showed a significant increase in the primary particle size range between 30 and $50 \mathrm{~nm}$. The maximum $\mathcal{E}_{50}, 15.8$, occurred at $42 \mathrm{~nm}$. At primary particle size $<30$ and $>50 \mathrm{~nm}$, the average $\varepsilon_{50}$ value was $0.70 \pm 0.23$. Both data sets in Figure 6 were fitted to (8). The fitted equation had $r^{2}$ value of 0.48 and 0.99 , for $\varepsilon_{20}$ and $\varepsilon_{50}$, respectively. Results showed that regardless of particle size, lipid peroxidation was increased approximately by $70 \%$ at EC50. However, there was 


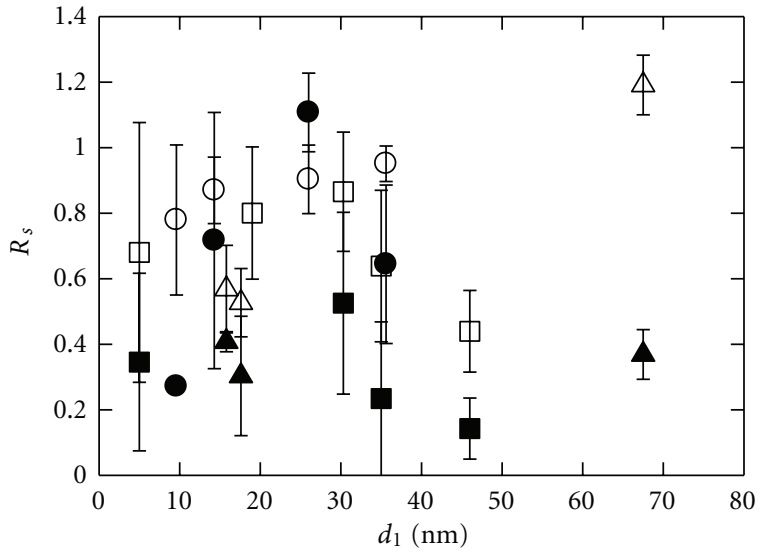

Figure 7: Normalized specific growth $\left(R_{s}\right)$ for three particletypes. Circles are $\mathrm{SiO}_{2}$, triangles are $\mathrm{Al}_{2} \mathrm{O}_{3}$, and squares are $\mathrm{TiO}_{2}$. Open symbols are $100 \mathrm{mg} / \mathrm{L}$ of exposure dosage. Solid symbols are $1000 \mathrm{mg} / \mathrm{L}$ of exposure dosage. Experimental conditions: initial algae concentration $=1.4 \pm 0.9 \times 10^{6} \mathrm{cell} / \mathrm{mL}$, test duration $=4$ days, and initial test volume $=200 \mathrm{~mL}$.

an increase in $\varepsilon_{50}$ between 30 and $50 \mathrm{~nm}$, with a maximum of $16.6 \mathrm{~L} / \mathrm{g} \mathrm{TiO}_{2}$ at $40.8 \mathrm{~nm}$.

Figure 7 shows the normalized specific cell growth $\left(R_{s}\right)$ in the presence of nanosized $\mathrm{Al}_{2} \mathrm{O}_{3}, \mathrm{SiO}_{2}$, and $\mathrm{TiO}_{2}$ at various $d_{1}$ values and two particle concentrations of 100 and $1000 \mathrm{mg} / \mathrm{L}$. As the primary particle size increased from 15.8 to $67.5 \mathrm{~nm}$ for $100 \mathrm{mg} / \mathrm{L}$ of $\mathrm{Al}_{2} \mathrm{O}_{3}$, the NSG increased from $0.57 \pm 0.13$ to $1.20 \pm 0.09$, respectively. $\mathrm{As}_{\mathrm{SiO}_{2}}$ size increased from 9.6 to $35.6 \mathrm{~nm}$ at $100 \mathrm{mg} / \mathrm{L}$, the $R_{s}$ increased from $0.78 \pm 0.23$ to $0.95 \pm 0.05$, respectively. $R_{s}$ reached a maximum of $0.84 \pm 0.18$ at $30.3 \mathrm{~nm}$ when $\mathrm{TiO}_{2}$ concentration was $100 \mathrm{mg} / \mathrm{L}$. The $R_{s}$ then decreased from $0.84 \pm 0.18$ to $0.44 \pm 1.2$ as particle size increased from 30.3 to $45.8 \mathrm{~nm}$. For both type and size, $\mathrm{TiO}_{2}$ at concentration of $1000 \mathrm{mg} / \mathrm{L}$ had a greater effect on the $R_{s}$ than at $100 \mathrm{mg} / \mathrm{L}$, except for $\mathrm{SiO}_{2} 26 \mathrm{~nm}$. The $\mathrm{Al}_{2} \mathrm{O}_{3}$ was at $1000 \mathrm{mg} / \mathrm{L}$ and the $R_{s}$ was reduced from $0.44 \pm 1.2$ to $0.36 \pm 0.05$ as $\mathrm{Al}_{2} \mathrm{O}_{3}$ particle size was increased from 45.8 to $67.5 \mathrm{~nm}$. The greatest impact on $R_{s}$ by $\mathrm{TiO}_{2}$ at $1000 \mathrm{mg} / \mathrm{L}$ was at $d_{1}$ of $46 \mathrm{~nm}$ with an $R_{s}$ of $0.14 \pm 0.09$. Treatment with $\mathrm{SiO}_{2}$ at $1000 \mathrm{mg} / \mathrm{L}$ concentration caused $R_{s}$ to increase from $0.27 \pm 0.01$ to $1.1 \pm 1.2$ as particle size increased from 9.6 to $26 \mathrm{~nm}$, respectively. The $R_{s}$ decreased from $1.1 \pm 0.12$ at $26 \mathrm{~nm}$ to $0.64 \pm 0.24$ at $35.6 \mathrm{~nm}$, in the presence of $1000 \mathrm{mg} / \mathrm{L}$ of $\mathrm{SiO}_{2}$. The $R_{s}$ responded similarly to $100 \mathrm{mg} / \mathrm{L}$ of $\mathrm{Al}_{2} \mathrm{O}_{3}$ and $\mathrm{SiO}_{2}$. As both particles increased in $d_{1}$, the $R_{s}$ increased. Figure 7 shows no apparent difference in the response between the two types of NP.

Figure 8 gives plots of the normalized specific chlorophyll a $(Y)$ for $\mathrm{Al}_{2} \mathrm{O}_{3}, \mathrm{SiO}_{2}$, and $\mathrm{TiO}_{2}$ at several primary particle sizes and two particle concentrations (e.g., 100 and $1000 \mathrm{mg} / \mathrm{L}) . \mathrm{Al}_{2} \mathrm{O}_{3}$ at concentration of $100 \mathrm{mg} / \mathrm{L}$ increased the $Y$ by an average of $71 \%$ between 15.8 and $17.6 \mathrm{~nm}$. The largest $\mathrm{Al}_{2} \mathrm{O}_{3}$ at $100 \mathrm{mg} / \mathrm{L}$ increased the $Y$ to $3.25 \pm$ 2.16. $\mathrm{Al}_{2} \mathrm{O}_{3}$ at $15.8 \mathrm{~nm}$ and $1000 \mathrm{mg} / \mathrm{L}$ decreased the $Y$ to $0.78 \pm 0.70$; however, this was not statistically different from the control. There was no difference between $\mathrm{Al}_{2} \mathrm{O}_{3}$ and

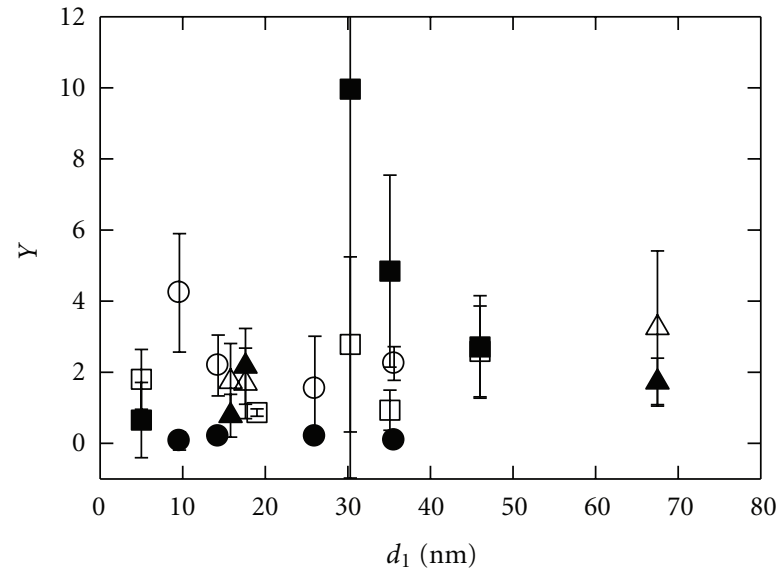

Figure 8: Normalized specific chlorophyll $(Y)$ for three-NP samples. Circles are $\mathrm{SiO}_{2}$, triangles are $\mathrm{Al}_{2} \mathrm{O}_{3}$, and squares are $\mathrm{TiO}_{2}$. Solid symbols are $100 \mathrm{mg} / \mathrm{L}$ of exposure dosage. Closed symbols are $1000 \mathrm{mg} / \mathrm{L}$ of exposure dosage. Experimental conditions: initial algae concentration $=1.4 \pm 0.9 \times 10^{6} \mathrm{cell} / \mathrm{mL}$, test duration $=4$ days, and initial test volume $=200 \mathrm{~mL}$.

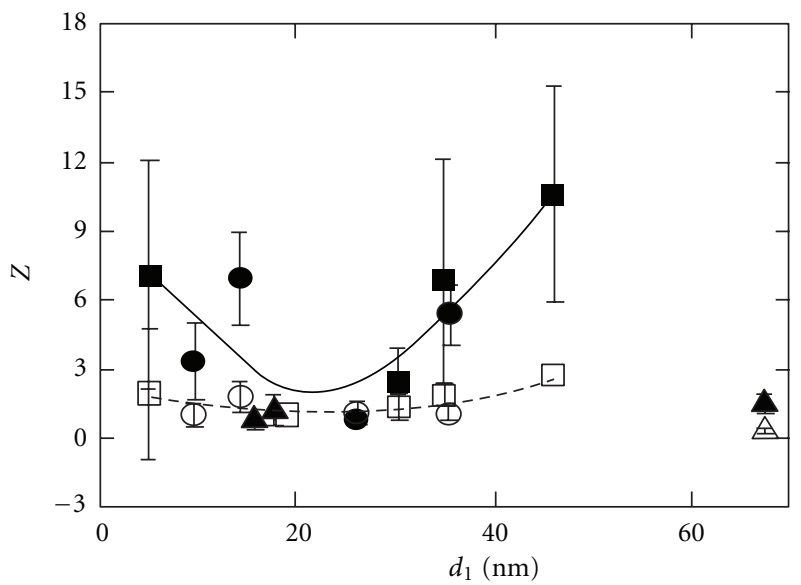

FIGURE 9: Normalized specific lipid oxidation $(Z)$ for three types of NP. Circles are $\mathrm{SiO}_{2}$, triangles are $\mathrm{Al}_{2} \mathrm{O}_{3}$, and squares are $\mathrm{TiO}_{2}$. Open symbols are $100 \mathrm{mg} / \mathrm{L}$. Solid symbols are $1000 \mathrm{mg} / \mathrm{L}$. Line is fitted 4-parameter Gaussian equation (9) in SigmaPlot ver. 9.01. Experimental conditions: initial algae concentration $=1.4 \pm 0.9 \times$ $10^{6} \mathrm{cell} / \mathrm{mL}$, test duration $=4$ days, and initial test volume $=200 \mathrm{~mL}$.

the control with respect to concentration or size. $\mathrm{SiO}_{2}$ at a concentration of $100 \mathrm{mg} / \mathrm{L}$ significantly increased the $Y$ at all $d_{1}$ values compared to the control, except at $26 \mathrm{~nm}$. $\mathrm{SiO}_{2}$ at concentration of $1000 \mathrm{mg} / \mathrm{L}$ significantly decreased the $Y$ by $84 \pm 4 \%$ the control at all $d_{1}$ values. As $d_{1}$ value of $\mathrm{TiO}_{2}$ at a concentration of $100 \mathrm{mg} / \mathrm{L}$ increased, the $Y$ increased; however, the average $Y$ at this treatment was not different from the control. The $\mathrm{TiO}_{2}$ at $1000 \mathrm{mg} / \mathrm{L}$ increased the $Y$ by a factor of 10 over the control level as the particle size increased from 4.8 to $30.3 \mathrm{~nm}$.

Figure 9 is a plot of normalized specific $\operatorname{MDA}(Z)$ at various $d_{1}$ values for $\mathrm{Al}_{2} \mathrm{O}_{3}, \mathrm{SiO}_{2}$, and $\mathrm{TiO}_{2}$ at two particle concentrations (e.g., 100 and $1000 \mathrm{mg} / \mathrm{L}$ ). The $\mathrm{Al}_{2} \mathrm{O}_{3}$ at 
a concentration of $100 \mathrm{mg} / \mathrm{L}$ resulted in an average $Z$ of $1.39 \pm 0.14$. The maximum of 2.7 occurred for the $\mathrm{TiO}_{2}$ concentration of $100 \mathrm{mg} / \mathrm{L}$ at $46 \mathrm{~nm}$. The minimum of 0.29 occurred for the $\mathrm{Al}_{2} \mathrm{O}_{3}$ concentration of $1000 \mathrm{mg} / \mathrm{L}$ at $67.5 \mathrm{~nm}$. The $1000 \mathrm{mg} / \mathrm{L}$ treatments significantly $(\alpha=0.05)$ increased normalized specific MDA for all samples, but $\mathrm{SiO}_{2}$ at $26 \mathrm{~nm}$. $\mathrm{SiO}_{2}$ at $26 \mathrm{~nm}$ decreased the normalized specific MDA to 0.86 from control levels. $\mathrm{Al}_{2} \mathrm{O}_{3}$ at a concentration of $100 \mathrm{mg} / \mathrm{L}$ significantly $(\alpha=0.05)$ decreased the normalized specific MDA compared to the control. $\mathrm{SiO}_{2}$ and $\mathrm{TiO}_{2}$ at a concentration of $100 \mathrm{mg} / \mathrm{L}$ significantly $(\alpha=0.001)$ increased the normalized specific MDA compared to the control. The average normalized specific MDA for the $1000 \mathrm{mg} / \mathrm{L}$ of $\mathrm{Al}_{2} \mathrm{O}_{3}$ was $1.14 \pm 0.13$. This was significantly higher than the control $(\alpha=0.05)$. The $\mathrm{SiO}_{2}$ and $\mathrm{TiO}_{2}$ were fitted with (9), represented as lines in Figure 9:

$$
Z=d_{1}{ }^{1}+a^{\prime \prime \prime} \exp \left[-0.5\left\{\frac{\left(d_{1}-d_{1}{ }^{2}\right)}{b^{\prime \prime}}\right\}^{2}\right],
$$

where $Z$ is the normalized specific lipid peroxidation, $d_{1}$ is the ENP size $(\mathrm{nm}), d_{1}{ }^{2}$ is the ENP size $(\mathrm{nm})$ which the minimum value of $Z$ occurs, $a^{\prime \prime \prime}$ and $b^{\prime \prime}$ are fitting parameters, and $y_{0}{ }^{\prime}$ is value at which the equation crosses the $y$ intercept. $\mathrm{Al}_{2} \mathrm{O}_{3}$ was not included in model fitting because there were not differences in $Z$ across the ENP size profile. This was as expected as $\mathrm{Al}_{2} \mathrm{O}_{3}$ is non-photocatalytic. The correlation coefficient $\left(r^{2}\right)$ was 0.67 and 0.68 for 100 and $1000 \mathrm{mg} / \mathrm{L}$, respectively. The average minimum value for the fitted equation occurs at $22.1 \pm 0.3 \mathrm{~nm}$ for both 100 and $1000 \mathrm{mg} / \mathrm{L}$ treatments.

\section{Discussion}

The discussion will be divided into sections of different ENP materials. The sequence of the section will be from $\mathrm{NP}$ with the least number of influential factors (e.g., $\mathrm{Al}_{2} \mathrm{O}_{3}$ ) to that of the most number of influential factors (e.g., $\mathrm{TiO}_{2}$ ). Factors such as water solubility, light availability, flocculation, photocatalytic properties, and ENP size that may impact the algae.

4.1. Aluminum Oxide. Aluminum oxide is the ENP with least number of influential factors in terms of the response by the algae and NP properties. The solubility of $\mathrm{Al}_{2} \mathrm{O}_{3}$ was not considered a factor in the toxicity seen in Figure 1. Unlike other NM such as CdSe that may bring about toxic metals such as $\mathrm{Cd}^{2+}[26,27], \mathrm{Al}_{2} \mathrm{O}_{3}$ would not generate enough $\mathrm{Al}^{3+}$ to cause the decreased growth. Gensemer and Playle [28] reported aluminum toxicity to $P$. subcapitata (formally known as $S$. capricornutum), with an EC value of $460 \mu \mathrm{g} / \mathrm{L}$ based on the biomass and $1,320 \mu \mathrm{g} / \mathrm{L}$ based on reduction of cell counts, respectively. The $\mathrm{pH}$ range of the above study was 7 to 8.2 , which was similar to this study. Metal ions are considered the most bioavailable/toxic species [29]. Using equilibrium constant reported by Sparks [30], the concentration of $\left(\mathrm{Al}^{3+}\right)$ from solubility of $\gamma-\mathrm{Al}_{2} \mathrm{O}_{3}(\mathrm{c})$ was calculated to be in the range between $10^{-12.5} \mathrm{~mol} / \mathrm{L}$ at $\mathrm{pH}$
8 and $10^{-9.5} \mathrm{~mol} / \mathrm{L}$ at $\mathrm{pH}$ 7. The concentration was several orders of magnitude smaller than what caused significant responses in other algal studies and were not considered the cause of the adverse effects observed. Additionally, $\mathrm{Al}_{2} \mathrm{O}_{3}$ is not a photocatalyst. In Figures 3 and 9, the degree of lipid peroxidation was reduced compared to $\mathrm{SiO}_{2}$ and $\mathrm{TiO}_{2}$. The increase in $Z$ (normalized specific MDA) for $\mathrm{Al}_{2} \mathrm{O}_{3}$ (Figure 3 ) is most likely due to measurements approaching the detection limits of the method $(\approx 0.2 \mu \mathrm{M}$ as malondialdehyde-thiobarbituric acid complex (MDATBA)). In combination with low cell counts at high NP concentration, low MDA-TBA will give large variation in normalized specific lipd peroxidation, $Z$. This indicates that $\mathrm{Al}_{2} \mathrm{O}_{3}$ did not increase the ROS in the system. Therefore, ROS was also not considered a factor in $\mathrm{Al}_{2} \mathrm{O}_{3}$ toxicity.

$\mathrm{Al}_{2} \mathrm{O}_{3} \mathrm{NP}$ did not affect the normalized specific lipid peroxidation, $Z$, or the chlorophyll a content of the $P$. subcapitata cells. However, $\mathrm{Al}_{2} \mathrm{O}_{3} \mathrm{NP}$ did affect the growth of the algal cells. This disagreed with Ji et al. [6] who reported that nano- $\mathrm{Al}_{2} \mathrm{O}_{3}$ did not have a significant effect on Chlorella sp. Several factors that govern the effect of $\mathrm{Al}_{2} \mathrm{O}_{3}$ on algal growth included flocculation, light availability, nutrient availability, and primary particle size, $d_{1}$. First, flocculation was affected by the surface charge (i.e., $\mathrm{pH}_{\mathrm{pzc}}$ ) of both the algal cells and $\mathrm{Al}_{2} \mathrm{O}_{3}[31,32] . \mathrm{Al}_{2} \mathrm{O}_{3}$ has a $\mathrm{pH}_{\mathrm{pzc}}$ of $8.2-$ 9.1 [30] and P. subcapitata has a $\mathrm{pH}_{\mathrm{pzc}}$ of about 2 [31]. The difference in $\mathrm{pH}_{\mathrm{pzc}}$ between $\mathrm{Al}_{2} \mathrm{O}_{3}$ and algal cells will induce flocculation and increase the apparent density of the algae [31]. In turn, the ability of the algal cells to remain buoyant will decrease as seen with Microcystis spp. and clay aggregation [32]. In the absence of ENP, as algae cells settle in a pond or river, the light and nutrient availability will change [33]. In most cases, these changes do not favor algal growth [33]. Second, $\mathrm{Al}_{2} \mathrm{O}_{3}$ can influence the nutrient availability. $\mathrm{Al}_{2} \mathrm{O}_{3}$ can affect the nutrient availability due to adsorption [34]. Speohr and Milner [35] related the availability of nutrients to the chlorophyll content in algal cells (Figures 2 and 8). In this study the possible nutrient adsorption was most prevalent when $\mathrm{Al}_{2} \mathrm{O}_{3}$ concentration was greater than $100 \mathrm{mg} / \mathrm{L}$ (Figure 2). Finally, NP which has limited solubility under the experimental conditions will increase the turbidity of the test sample. This turbidity will cause a shading effect which will decrease the available light to the algae in photosynthesis [36]. Decreased available light has been shown to decrease chlorophyll content of algae in sponges and decrease growth rate of $D$. tertiolecta. The shading effect would be from the $\mathrm{Al}_{2} \mathrm{O}_{3}$ flocculated with the algae and those NP particles which remain unattached [31]. The flocculation between NP and the algae cells resulted in incomplete, multilayered surface coverage [31].

The effect of NP size on growth is seen in Figure 7. Increased growth occurred with increasing the primary particle size of $\mathrm{Al}_{2} \mathrm{O}_{3}, d_{1}$. Smaller particles will increase the turbidity of the suspension more than larger particles on the same mass basis, which will increase the effect of shading on the algal cells. The adsorption capacity of nutrients will be greater at smaller $d_{1}$ than larger $d_{1}$. With more nutrients being removed from the suspension, the algae will have reduced growth. 
4.2. Silicon Dioxide. $\mathrm{SiO}_{2} \mathrm{NM}$ has the same influential factors (nutrient limiting, light limiting) as $\mathrm{Al}_{2} \mathrm{O}_{3}$ but has the additional effect on increasing the lipid peroxidation. Like $\mathrm{Al}_{2} \mathrm{O}_{3}$, the solubility of $\mathrm{SiO}_{2} \mathrm{NP}$ was not considered a factor affecting the EC value. Van Hoecke et al. [4] found that $\mathrm{SiO}_{2}$ at particle size of 12.5 and $27.0 \mathrm{~nm}$ had a $72 \mathrm{~h}$ specific growth rate EC20 of $20.0 \pm 5.0$ and $28.8 \pm 3.2 \mathrm{mg} / \mathrm{L}$, respectively. Of the NP concentrations used in the Van Hoecke et al. [4] study, the highest concentration of dissolved Si was $4.1 \mathrm{mg} / \mathrm{L}$ at $\mathrm{pH}$ 7.5. The measured dissolved Si at EC20 in the present study was $234 \mathrm{mg} / \mathrm{L}$, which was adequate to affect the growth of algae. Therefore, dissolved $\mathrm{Si}$ was not considered a major factor in $\mathrm{SiO}_{2}$ toxicity. The difference in $\mathrm{EC}$ values between this work and that of Van Hoecke et al. [4] could be due to different initial algal densities. We used an initial cell density of $10^{6}$ and Van Hoecke et al. [4] used $10^{5} \mathrm{cell} / \mathrm{mL}$. $\mathrm{SiO}_{2}$ did not play a major role in the growth of $P$. subcapitata over the concentration range tested in ourwork, which agreed with Ji et al. [6] who reported little effect on Chlorella sp. Growth at $\mathrm{SiO}_{2}$ concentration of $1000 \mathrm{mg} / \mathrm{L}$ in the size range of 20 $50 \mathrm{~nm}$.

$\mathrm{SiO}_{2}$ caused an increase in lipid peroxidation (Figures 3 and 9). An increase in $\mathrm{SiO}_{2}$ caused an increased average normalized specific lipid peroxidation, $Z$, (Figure 3). Although not considered a photocatalyst, $\mathrm{SiO}_{2}$ has been observed to produce similar photosensitive effects, including increased ROS levels and reduced glutathione levels, as a photocatalyst [1]. In this study, the effect of $\mathrm{SiO}_{2} \mathrm{NP}$ on normalized specific MDA, $Z$, could be due more to limit light availability than the production of ROS directly. Limited light availability has been shown to produce ${ }^{1} \mathrm{O}_{2}$ under aerobic conditions through back flow of electrons to excite $\mathrm{P}_{680}$ to ${ }^{3} \mathrm{P}_{680}$ [37, 38]. Here $\mathrm{P}_{680}$ is the reaction center containing chlorophyll within the thylakoid membrane. The ROS generated in this reaction is responsible for increasing normalized specific lipid peroxidation, $Z$. The decrease in normalized specific MDA as the concentration of $\mathrm{SiO}_{2} \mathrm{ENP}$ increase was due to turbidity increase and light availability decrease as affected by the particle size. Rayleigh theory of light scattering predicts that light scattering is proportional to the ratio between the radius of a particle and a given wavelength of light with light scattering efficiency being proportional to the fourth power of particle radius [36]. This would reduce the back flow of electrons. The growth of cells at $1000 \mathrm{mg} / \mathrm{L}$ (Figure 7) was inversely proportional to the lipid peroxidation at $1000 \mathrm{mg} / \mathrm{L}$ (Figure 9). This was also affected by the lack of flocculation between the algae and the $\mathrm{SiO}_{2}$ which resulted in evenly distributed shading effect throughout the algal cells.

$\mathrm{SiO}_{2}$ affected the chlorophyll content of the algal cells (Figures 2 and 8). Low NP concentration increased Chla, whereas high NP concentration decreased it. Results showed that limited light availability can affect the chlorophyll content in algae [39, 40]. The reduction in light availability would encourage the algae to produce more chlorophyll per cell [41]. At low concentrations the algae will attempt to overcome the decreased light availability. Following the Rayleigh theory of light scattering, the turbidity of the solutions increased with decreased NP size on the same mass basis (Figure 8 open circles). With increased NP size the light availability to the algae increased; the less chlorophyll a the algae need to produce. The Chla was reduced significantly at $1000 \mathrm{mg} / \mathrm{L} \mathrm{SiO}_{2}$ (Figure 8). Manganese deficiency has been the cause of decreased chlorophyll content in Chlorella fusca and Chlorella vulgaris [42]. Nutrient limitation due to the adsorption of nutrients on $\mathrm{SiO}_{2}$ may have caused the decreased Chla. The $\mathrm{SiO}_{2}$ has a $\mathrm{pH}_{\mathrm{pzc}}$ about 2, similar to that of algae. There have been many studies that show adsorption of cations to NM [43-45]. In particular, $\mathrm{SiO}_{2}$ has shown to adsorb $\mathrm{Mg}(\mathrm{II}), \mathrm{Mn}(\mathrm{II}), \mathrm{Na}(\mathrm{I}), \mathrm{K}(\mathrm{I}), \mathrm{Cu}(\mathrm{II})$, and $\mathrm{Zn}(\mathrm{II})$ [30] which are all required nutrients from algal cell health.

4.3. Titanium Dioxide. $\mathrm{TiO}_{2}$ is the $\mathrm{NP}$ with the most number of influential factors that affect the responses of $P$. subcapitata. $\mathrm{TiO}_{2}$ with $\mathrm{pH}_{\mathrm{pzc}}$ of 6.5 acted similarly to $\mathrm{Al}_{2} \mathrm{O}_{3}$ by flocculating with algae, adsorbing nutrients, and limiting light availability. $\mathrm{TiO}_{2}$ also acted similarly to $\mathrm{SiO}_{2}$ by having a portion of the NP remain free in suspension, limiting light availability and affecting lipid peroxidation. However, unlike $\mathrm{SiO}_{2}, \mathrm{TiO}_{2}$ is a known photocatalyst that generates ROS.

NP is soluble in water leading to release of metal ions $\left(\mathrm{M}^{n+}\right)$ ions, which are toxic to organisms $[28,29]$. This could not be a key factor in the case of $\mathrm{TiO}_{2}$. There is little information regarding the toxicity of $\mathrm{Ti}^{4+}$. Thermodynamically, the formation of $\mathrm{Ti}^{4+}$ in aqueous solution will be limited due to the formation of dissolved $\mathrm{TiO}_{2}$ [46]. This will have minimal effect on organisms because of the small percent of total metal that is present as free metal ion. Therefore, the solubility of $\mathrm{TiO}_{2}$ was not a major factor controlling the responses of algae to this NP.

Major factors affecting the algal responses include light availability, flocculation, particle size, and photoactivity. These factors are interrelated. When $\mathrm{TiO}_{2}$ and algal cells are introduced into the suspension, flocculation takes place right away [31]. Like $\mathrm{Al}_{2} \mathrm{O}_{3}, \mathrm{TiO}_{2}$ will affect the apparent density of the algal cells. Flocculation between algal cells and $\mathrm{TiO}_{2}$ was observed and was consistent with Lin [31] which reported absorption of $\mathrm{TiO}_{2}$ to $P$. subcapitata. The flocculation with $\mathrm{TiO}_{2}$ has the effect of bringing the algae in direct contact with the ROS-generating $\mathrm{TiO}_{2}$ (Figure 3). The lipid peroxidation may have been affected by the adsorption of NP to the surface of the algal cells. The direct transfer of ROS from the point of generation to the surface of algal cells is important. This can be exemplified by calculating the distance highly reactive hydroxyl radical $\left(\mathrm{OH}^{\bullet}\right)$ will travel before it reaches the end of the first half-life. The half-life of ROS is on the order of milliseconds [47, 48]. Lee et al. [49] used the diffusion layer thickness of $800 \mathrm{~nm}$ to calculate $\mathrm{Ag}^{+}$diffusion to $P$. subcapitata. The hydroxyl radical $\left(\mathrm{OH}^{\bullet}\right)$ diffusion coefficient is $2.3 \times 10^{-9} \mathrm{~m}^{2} / \mathrm{s}$ [50]. From Fick's second law of diffusion and assuming the reaction rate of $\mathrm{OH}^{-}$is on the order of milliseconds, then the $\mathrm{OH}^{\bullet}$ would travel approximately $18 \mathrm{~nm}$ before one half of the $\mathrm{OH}^{*}$ would react with other oxygen species in the water. The concentration of $\mathrm{OH}^{\bullet}$ would be reduced by $>99 \%$ by the time and would diffuse to the surface of the algal cell. It is feasible that if the NP and algae are not in contact, the ROS will not bring about lipid peroxidation. The lipid peroxidation was maximized at $d_{1}$ of $42 \mathrm{~nm}$ (Figure 6) which correlates with the maximum size 
effect on growth (Figure 4). The number of particles that flocculate with an algal cell might be correlated to $d_{1}$. Larger $d_{1}$ might decrease the number of NP that will flocculate with algae. This will also affect available light. The incomplete, multilayered coverage of the algal cells, like $\mathrm{Al}_{2} \mathrm{O}_{3}$, may decrease light availability to the algal cells. As discussed with $\mathrm{Al}_{2} \mathrm{O}_{3}$ and $\mathrm{SiO}_{2}$, the decrease in light will affect the growth and chlorophyll content.

The primary particle size of $\mathrm{TiO}_{2}, d_{1}$, played a role in algal growth, chlorophyll content of algal cells, and lipid peroxidation of algal cells (Figures 4-6). All of these endpoints have maximum effect values at the same particle size of $42 \mathrm{~nm}$. Like $\mathrm{Al}_{2} \mathrm{O}_{3}$ and $\mathrm{SiO}_{2}$, nutrients such as $\mathrm{Cu}, \mathrm{Fe}$, or $\mathrm{N}$ would be imitated due to the scavenged by NP, which in turn could affect the chlorophyll content. It has been suggested that NP can decrease bioavailability of nutrients, which would contribute to toxicity [6]. The smaller the $d_{1}$, the greater the specific surface area and the more nutrients would be adsorbed. Gao et al. [51] observed that maximum adsorption density of $\mathrm{Cd}^{2+}\left(\Gamma_{\max }\right)$ varied inversely proportional to the NP size. That relationship would be true for nutrients such as $\mathrm{Cu}, \mathrm{Fe}$, or $\mathrm{N}$, which in turn would affect the chlorophyll a production and algal growth [35]. The $d_{1}$ primarily affect the critical specific chlorophyl (Figure 5). Lin [31] studied the adsorption of $\mathrm{TiO}_{2}$ onto P. subcapitata and reported that at $\mathrm{pH} 7.3$ and initial $\mathrm{TiO}_{2}$ of $150 \mathrm{mg} / \mathrm{L}$, the $\mathrm{TiO}_{2}$ uptake (no. $\mathrm{TiO}_{2}$ per algal cell) was constant at $3 \times 10^{5} \mathrm{TiO}_{2}$ particles per algal cell. At higher concentration of $\mathrm{TiO}_{2}$, there will be no additional uptake.

The extent of lipid peroxidation has been related to the amount of reactive oxygen species in many different systems including humans to fish to bacteria [43-55]. Generation of ROS by NP photocatalysts is related to the size and the type of NP $[10,56]$. Size of the particles controls the band gap and surface area $[8,11]$. The band gap determines the level of light energy that is converted to protons and the surface area affects the recombination of election-hole pairs. Many studies have shown that optimum degradation of organic compounds occurs of $\mathrm{TiO}_{2}$ between 3.8 and $40 \mathrm{~nm}$ [36, 57-61]. These values are smaller than what is observed in Figure 6. The lipid peroxidation in this study may be influenced by adsorption of NP to the surface of the algae. The half-life of ROS is on the order of microseconds, for example, the superoxide anion $\left({ }^{\circ} \mathrm{O}_{2}{ }^{-}\right)$has a half-life of $1 \mu$ s and hydrogen peroxide $\left(\mathrm{H}_{2} \mathrm{O}_{2}\right)$ has a half-life of $1 \mathrm{~ms}[48,49]$. Due to this time scale, it is feasible that if the NP and algae are not in contact, the ROS will not prompt lipid peroxidation. However, no literature was available regarding how $d_{1}$ affects the aggregation between algae and NP. Additionally, light availability is being optimized for ROS generation at $d_{1}$ of ca. $42 \mathrm{~nm}$. At $d_{1}$ smaller than $42 \mathrm{~nm}$, the surface density of particles increases, which decreases the light availability to the NP in direct contact with the surface of the cells.

\section{Conclusions}

This research was undertaken to answer the following questions. How toxic is the $\mathrm{TiO}_{2}$ to algae? What does NP size play in toxicity? Does the type of NP play a role in toxicity, chlorophyll content, and lipid peroxidation?

The effects of photocatalytic $\mathrm{TiO}_{2}$ on algae was compared to that of non-photocatalytic nanoparticles (e.g., $\mathrm{Al}_{2} \mathrm{O}_{3}$ and $\mathrm{SiO}_{2}$ ). Based on results, it can be concluded that $\mathrm{TiO}_{2}$ is "harmful-toxic" between a $d_{1}$ of 30 to $60 \mathrm{~nm}$ and nontoxic at $d_{1}<30 \mathrm{~nm}$ and $d_{1}>60 \mathrm{~nm}$. The term harmful is defined as measurement endpoints from 10-100 mg/L [62]. The term non-toxic is defined as measurement endpoints $>100 \mathrm{mg} / \mathrm{L}$ [62]. The most important factor was the surface charge of the material as it affected the aggregation between algae and NP, which in turn affected lipid peroxidation, chlorophyll a content, and growth.

If nanoparticles were released into the environment, algae would be flocculated dependent on the extent of surface charge of the nanoparticles and the algal cells. The algae will attempt to overcome the shading effect by increasing the chlorophyll content in order to optimize the light availability. With a high degree of light scattering, that is, limited light availability, lipid peroxidation may be generated by "back flow of electrons in the PSII from the semiquinone acceptor to the $S_{2,3}$ oxidation states of the donor side" [37]. Additionally, as the algae are removed from the water column by an increased rate of settling, the light availability will continue to decrease. Exposure time in the water column will be limited, in most cases, due to flocculation and subsequent settling out of nanoparticles in the water column.

Lipid peroxidation was the only measurement used to determine reactive oxygen species activity. However, it is suggested that several additional biochemical markers be measured in order to observe how the defensive mechanism response of algae in response to nanoparticles. It is therefore suggested that subchronic endpoints be a measurement for future work, including, but not limited to, glutathione, superoxide dismutase, and various direct ROS assays. Additionally, the response of several additional species of algae is recommended for the purpose of comparison. This will add in verifying the results of this study.

\section{Acknowledgments}

Dr. Y. L. Liao, a visiting scholar from Taiwan, synthesized $\mathrm{TiO}_{2}$ nanoparticles of various sizes used in this study. This paper was funded by USEPA STAR Grant no. R83172101. Dr. Nora Savage was the project manager. Results, discussions, and conclusions are those of the authors and should not be interpret, as endorsement of the funding agency. Sources of nanoparticles studied came from the following suppliers: Degussa Corp., Allied High Tech Products, Nanostructured and Amorphous Materials, Inc., and Sachtleben Chemicals. The authors have no direct financial interest in or relationship with any of the above companies.

\section{References}

[1] W. Lin, Y. W. Huang, X. D. Zhou, and Y. Ma, "In vitro toxicity of silica nanoparticles in human lung cancer cells," Toxicology and Applied Pharmacology, vol. 217, pp. 252-259, 2006. 
[2] A. J. Wagner, C. A. Bleckmann, R. C. Murdock, A. M. Schrand, J. J. Schlager, and S. M. Hussain, "Cellular interaction of different forms of aluminum nanoparticles in rat alveolar macrophages," Journal of Physical Chemistry B, vol. 111, no. 25, pp. 7353-7359, 2007.

[3] M. Bodo, G. Muzi, C. Bellucci et al., "Comparative in vitro studies on the fibrogenic effects of two samples of silica on epithelial bronchial cells," Journal of Biological Regulators and Homeostatic Agents, vol. 21, no. 3-4, pp. 97-104, 2007.

[4] K. Van Hoecke, K. A. C. De Schamphelaere, P. Van der Meeren, S. Lucas, and C. R. Janssen, "Ecotoxicity of silica nanoparticles to the green alga Pseudokirchneriella subcapitata: importance of surface area," Environmental Toxicology and Chemistry, vol. 27, no. 9, pp. 1948-1957, 2008.

[5] D. B. Warheit, T. R. Webb, K. L. Reed, S. Frerichs, and C. M. Sayes, "Pulmonary toxicity study in rats with three forms of ultrafine- $\mathrm{TiO}_{2}$ particles: differential responses related to surface properties," Toxicology, vol. 230, no. 1, pp. 90-104, 2007.

[6] J. Ji, Z. Long, and D. Lin, "Toxicity of oxide nanoparticles to the green algae Chlorella sp.," Chemical Engineering Journal, vol. 170, pp. 525-530, 2011.

[7] E. Pinto, T. C. S. Sigaud-Kutner, M. A. S. Leitão, O. K. Okamoto, D. Morse, and P. Colepicolo, "Heavy metal-induced oxidative stress in algae," Journal of Phycology, vol. 39, no. 6, pp. 1008-1018, 2003.

[8] L. Brus, "Electronic wave functions in semiconductor clusters: experiment and theory," Journal of Physical Chemistry, vol. 90, no. 12, pp. 2555-2560, 1986.

[9] Y. H. Tseng, H. Y. Lin, C. S. Kuo, Y. Y. Li, and C. P. Huang, "Thermostability of $\mathrm{Nano}^{-\mathrm{TiO}_{2}}$ and its photocatalytic activity," Reaction Kinetics and Catalysis Letters, vol. 89, pp. 63-69, 2006.

[10] S. Bakardjieva, J. Šubrt, V. Štengl, M. J. Dianez, and M. J. Sayagues, "Photoactivity of anatase-rutile $\mathrm{TiO}_{2}$ nanocrystalline mixtures obtained by heat treatment of homogeneously precipitated anatase," Applied Catalysis B, vol. 58, no. 3-4, pp. 193-202, 2005.

[11] H. Lin, C. P. Huang, W. Li, C. Ni, S. I. Shah, and Y. H. Tseng, "Size dependency of nanocrystalline $\mathrm{TiO}_{2}$ on its optical property and photocatalytic reactivity exemplified by 2-chlorophenol," Applied Catalysis B, vol. 68, pp. 1-11, 2006.

[12] C. Y. Liu and A. J. Bard, "Effect of excess charge on band energetics (optical absorption edge and carrier redox potentials) in small semiconductor particles," Journal of Physical Chemistry, vol. 93, no. 8, pp. 3232-3237, 1989.

[13] J. M. Nedeljković, M. T. Nenadović, O. I. Mićić, and A. J. Nozik, "Enhanced photoredox chemistry in quantized semiconductor colloids," Journal of Physical Chemistry, vol. 90, no. 1, pp. 12-13, 1986.

[14] U. Koch, A. Fojtik, H. Weller, and A. Henglein, "Photochemistry of semiconductor colloids. Preparation of extremely small $\mathrm{ZnO}$ particles, fluorescence phenomena and size quantization effects," Chemical Physics Letters, vol. 122, no. 5, pp. 507-510, 1985.

[15] F. Morazzoni, C. Canevali, N. Chiodini et al., "Nanostructured Pt-doped tin oxide films: sol-gel preparation, spectroscopic and electrical characterization," Chemistry of Materials, vol. 13, no. 11, pp. 4355-4361, 2001.

[16] R. Hardman, "A toxicologic review of quantum dots: toxicity depends on physicochemical and environmental factors," Environmental Health Perspectives, vol. 114, no. 2, pp. 165-172, 2006.
[17] S. Kashiwada, "Distribution of nanoparticles in the seethrough medaka (Oryzias latipes)," Environmental Health Perspectives, vol. 114, no. 11, pp. 1697-1702, 2006.

[18] L. K. Adams, D. Y. Lyon, and P. J. J. Alvarez, "Comparative ecotoxicity of nanoscale $\mathrm{TiO}_{2}, \mathrm{SiO}_{2}$, and $\mathrm{ZnO}$ water suspensions," Water Research, vol. 40, no. 19, pp. 3527-3532, 2006.

[19] United States Environmental Protection Agency, "Short-term methods for estimating the chronic toxicity of effluents and receiving waters to freshwater organisms," Tech. Rep. EPA-821-R-02-013, United States Environmental Protection Agency, Office of Water, Washington, DC, USA, 2002.

[20] D. Metzler, Effect of Food-Borne Cadmium on the Reproduction of Ceriodaphina Dubia [M.S. thesis], University of Delaware, Newark, Del, USA, 2003.

[21] C. I. Weber, L. A. Fay, G. B. Collins, D. E. Rathke, and J. Tobin, "A review of methods for the analysis of chlorophyll in periphyton and plankton of marine and freshwater systems," Tech. Rep. Technical bulletin OHSU-TB-15, Ohio State University Sea Grant Program, 1986.

[22] A. D. Eaton, L. S. Clesceri, and A. E. Greenberg, Standard Methods for the Examination of Water and Wastewater, American Public Health Association, American Water Works Association, and Water Environment Federation, Washington, DC, USA, 19th edition, 1995.

[23] P. C. Maness, S. Smolinski, D. M. Blake, Z. Huang, E. J. Wolfrum, and W. A. Jacoby, "Bactericidal activity of photocatalytic $\mathrm{TiO}_{2}$ reaction: toward an understanding of its killing mechanism," Applied and Environmental Microbiology, vol. 65, no. 9, pp. 4094-4098, 1999.

[24] United States Environmental Protection Agency, Toxicity Relationship Analysis Program. Version 1, United States Environmental Protection Agency, National Health and Environmental Effects Research Laboratory, Mid-continent Ecology Division, Duluth, Minn, USA, 2002.

[25] A. M. M. Goncalves, D. R. de Figureueiredo, and M. J. Pereira, "The effects of different salinity concentrations on growth of three freshwater green algae," Fresenius Environmental Bulletin, vol. 15, no. 11, pp. 1382-1386, 2006.

[26] S. H. Hsieh, K. P. Tsai, and C. Y. Chen, "The combined toxic effects of nonpolar narcotic chemicals to Pseudokirchneriella subcapitata," Water Research, vol. 40, no. 10, pp. 1957-1964, 2006.

[27] C. Kirchner, T. Liedl, S. Kudera et al., "Cytotoxicity of colloidal CdSe and CdSe/ZnS nanoparticles," Nano Letters, vol. 5, no. 2, pp. 331-338, 2005.

[28] R. W. Gensemer and R. C. Playle, "The bioavailability and toxicity of aluminum in aquatic environments," Critical Reviews in Environmental Science and Technology, vol. 29, no. 4, pp. 315-450, 1999.

[29] H. E. Allen, R. H. Hall, and T. D. Brisbin, "Metal speciation. Effects on aquatic toxicity," Environmental Science and Technology, vol. 14, no. 4, pp. 441-443, 1980.

[30] D. Sparks, Environmental Soil Chemistry, Academic Press, New York, NY, USA, 2nd edition, 2003.

[31] M. Y. Lin, Interactions between Titanium Dioxide Nanoparticles and Algal Cells at Moderate Particle Concentration [M.S. thesis], University of Delaware, Newark, Del, USA, 2008.

[32] J. M. H. Verspagen, J. Passarge, K. D. Jöhnk et al., "Water management strategies against toxic Microcystis blooms in the Dutch delta," Ecological Applications, vol. 16, no. 1, pp. 313327, 2006.

[33] R. G. Wetzel and, Limnology, Saunders College, New York, NY, USA, 2nd edition, 1985. 
[34] S.-F. Cheah, G. E. Brown Jr., and G. A. Parks, "XAFS spectroscopy study of $\mathrm{Cu}(\mathrm{II})$ sorption on amorphous $\mathrm{SiO}_{2}$ and gamma- $\mathrm{Al}_{2} \mathrm{O}_{3}$ : effect of substrate and time on sorption complexes," Journal of Colloid and Interface Science, vol. 208, no. 1, pp. 110-128, 1998.

[35] H. A. Speoher and H. W. Milner, "The chemical composition of Chlorella; effect of environmental conditions," Plant Physiology, vol. 24, no. 1, pp. 120-149, 1949.

[36] A. J. Maira, K. L. Yeung, C. Y. Lee, P. L. Yue, and C. K. Chan, "Size effects in gas-phase photo-oxidation of trichloroethylene using nanometer-sized $\mathrm{TiO}_{2}$ catalysts," Journal of Catalysis, vol. 192, no. 1, pp. 185-196, 2000.

[37] N. Keren, A. Berg, P. J. M. Van Kan, H. Levanon, and I. Ohad, "Mechanism of photosystem II photoinactivation and D1 protein degradation at low light: the role of back electron flow," Proceedings of the National Academy of Sciences of the United States of America, vol. 94, no. 4, pp. 1579-1584, 1997.

[38] Y. Nishiyama, S. I. Allakhverdiev, and N. Murata, "Inhibition of the repair of Photosystem II by oxidative stress in cyanobacteria," Photosynthesis Research, vol. 84, no. 1-3, pp. 1-7, 2005.

[39] T. E. Brown and F. L. Richardson, "The effect of growth environment on the physiology of algae: light intensity," Journal of Phycology, vol. 4, pp. 38-54, 1968.

[40] M. J. Behrenfeld, O. Prasil, M. Babin, and F. Bruyant, "In search of a physiological basis for covariations in light-limited and light-saturated photosynthesis," Journal of Phycology, vol. 40, no. 1, pp. 4-25, 2004.

[41] M. F. Colombo-Pallotta, E. García-Mendoza, and L. B. Ladah, "Photosynthetic performance, light absorption, and pigment composition of Macrocystis pyrifera (Laminariales, Phaeophyceae) blades from different depths," Journal of Phycology, vol. 42, no. 6, pp. 1225-1234, 2006.

[42] E. Kessler, "Effect of manganese deficiency on growth and chlorophyll content of algae with and without hydrogenase," Archiv für Mikrobiologie, vol. 63, no. 1, pp. 7-10, 1968.

[43] K. Hristovski, A. Baumgardner, and P. Westerhoff, "Selecting metal oxide nanomaterials for arsenic removal in fixed bed columns: from nanopowders to aggregated nanoparticle media," Journal of Hazardous Materials, vol. 147, no. 1-2, pp. 265-274, 2007.

[44] P. Liang, Y. Qin, B. Hu, C. Li, T. Y. Peng, and Z. Jiang, "Study of the adsorption behavior of heavy metal ions on nanometersize titanium dioxide with ICP-AES," Fresenius' Journal of Analytical Chemistry, vol. 368, no. 6, pp. 638-640, 2000.

[45] E. Vassileva, K. Hadjiivanov, T. Stoychev, and C. Daiev, "Chromium speciation analysis by solid-phase extraction on a high surface area $\mathrm{TiO}_{2}$," Analyst, vol. 125, no. 4, pp. 693-698, 2000.

[46] W. Stumm and J. J. Morgan, Aquatic Chemistry: Chemical Equilibria and Rates in Natural Waters, John Wiley and Sons, New York, NY, USA, 3rd edition, 1996.

[47] M. Reth, "Hydrogen peroxide as second messenger in lymphocyte activation," Nature Immunology, vol. 3, no. 12, pp. 1129 $1134,2002$.

[48] M. Drábková, B. Maršálek, and W. Admiraal, "Photodynamic therapy against cyanobacteria," Environmental Toxicology, vol. 22, no. 1, pp. 112-115, 2007.

[49] D. Y. Lee, C. Fortin, and P. G. Campbell, "Influence of chloride on silver uptake by two green algae, Pseudokirchneriella subcapitata and Chlorella pyrenoidosa," Environmental Toxicology and Chemistry, vol. 23, no. 4, pp. 1012-1018, 2004.

[50] I. M. Svishchev and A. Y. Plugatyr, "Hydroxyl radical in aqueous solution: computer simulation," Journal of Physical Chemistry B, vol. 109, no. 9, pp. 4123-4128, 2005.
[51] Y. Gao, R. Wahi, A. T. Kan, J. C. Falkner, V. L. Colvin, and M. B. Tomson, "Adsorption of cadmium on anatase nanoparticleseffect of crystal size and pH," Langmuir, vol. 20, no. 22, pp. 9585-9593, 2004.

[52] F. Wolfe-Simon, D. Grzebyk, O. Schofield, and P. G. Falkowski, "The role and evolution of superoxide dismutases in algae," Journal of Phycology, vol. 41, no. 3, pp. 453-465, 2005.

[53] C. M. Sayes, A. M. Gobin, K. D. Ausman, J. Mendez, J. L. West, and V. L. Colvin, "Nano- $\mathrm{C}_{60}$ cytotoxicity is due to lipid peroxidation," Biomaterials, vol. 26, no. 36, pp. 7587-7595, 2005.

[54] A. Valavanidis, T. Vlahogianni, M. Dassenakis, and M. Scoullos, "Molecular biomarkers of oxidative stress in aquatic organisms in relation to toxic environmental pollutants," Ecotoxicology and Environmental Safety, vol. 64, no. 2, pp. 178189, 2006.

[55] K. Kato, A. Tsuzuki, H. Taoda, Y. Torii, T. Kato, and Y. Butsugan, "Crystal structures of $\mathrm{TiO}_{2}$ thin coatings prepared from the alkoxide solution via the dip-coating technique affecting the photocatalytic decomposition of aqueous acetic acid," Journal of Materials Science, vol. 29, no. 22, pp. 59115915, 1994.

[56] M. Anpo, H. Nakaya, S. Kodama, Y. Kubokawa, K. Domen, and T. Onishi, "Photocatalytic hydrogenation of propyne with water on small-particle titania: size quantization effects and reaction intermediates," The Journal of Physical Chemistry, vol. 91, no. 16, pp. 4305-4310, 1987.

[57] K. Tanaka, M. F. V. Capule, and T. Hisanaga, "Effect of crystallinity of $\mathrm{TiO}_{2}$ on its photocatalytic action," Chemical Physics Letters, vol. 187, no. 1-2, pp. 73-76, 1991.

[58] Z. Zhang, C. C. Wang, R. Zakaria, and J. Y. Ying, "Role of particle size in nanocrystalline $\mathrm{TiO}_{2}$-based photocatalysts," Journal of Physical Chemistry B, vol. 102, no. 52, pp. 10871-10878, 1998.

[59] J. K. Yang and A. P. Davis, "Competitive photocatalytic oxidation of $\mathrm{Cu}(\mathrm{II})$-EDTA and Cd(II)_EDTA with illuminated $\mathrm{TiO}_{2}$," Environmental Science and Technology, vol. 35, no. 17, pp. 3566-3570, 2001.

[60] C. B. Almquist and P. Biswas, "Role of synthesis method and particle size of nanostructured $\mathrm{TiO}_{2}$ on its photoactivity," Journal of Catalysis, vol. 212, no. 2, pp. 145-156, 2002.

[61] H. J. Nam, T. Amemiya, M. Murabayashi, and K. Itoh, "Photocatalytic activity of sol-gel $\mathrm{TiO}_{2}$ thin films on various kinds of glass substrates: the effects of $\mathrm{Na}^{+}$and primary particle size," Journal of Physical Chemistry B, vol. 108, no. 24, pp. 82548259, 2004.

[62] C. Blaise, F. Gagné, J. F. Férard, and P. Eullaffroy, "Ecotoxicity of selected nano-materials to aquatic organisms," Environmental Toxicology, vol. 23, no. 5, pp. 591-598, 2008.

[63] C. D. Dong, Y. L. Liao, C. M. Kao, C. W. Chen, H. Y. Lin, and C. P. Huang, "Preparation of crystalline nanosized titania by microemulsion: evaluation of process variables," Advanced Oxidation Technology, vol. 10, no. 2, pp. 399-404, 2007.

[64] Aerosil, September 2009, http://www.aerosil.com/wps/PA_1_ 2_1RD/downloadMsds?id=6.

[65] A. K. Arora and Kamaluddin, "Role of metal oxides in chemical evolution: interaction of ribose nucleotides with alumina," Astrobiology, vol. 9, no. 2, pp. 165-171, 2009.

[66] K. Bourikas, T. Hiemstra, and W. H. Van Riemsdijk, "Ion pair formation and primary charging behavior of titanium oxide (anatase and rutile)," Langmuir, vol. 17, no. 3, pp. 749-756, 2001. 



The Scientific World Journal

Submit your manuscripts at

http://www.hindawi.com

\section{World Journal}

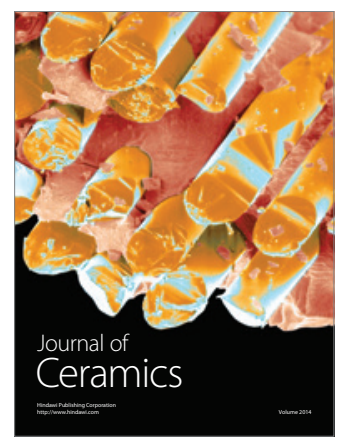

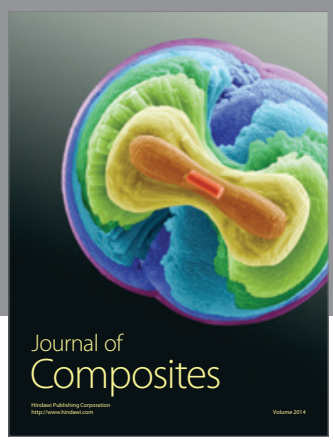
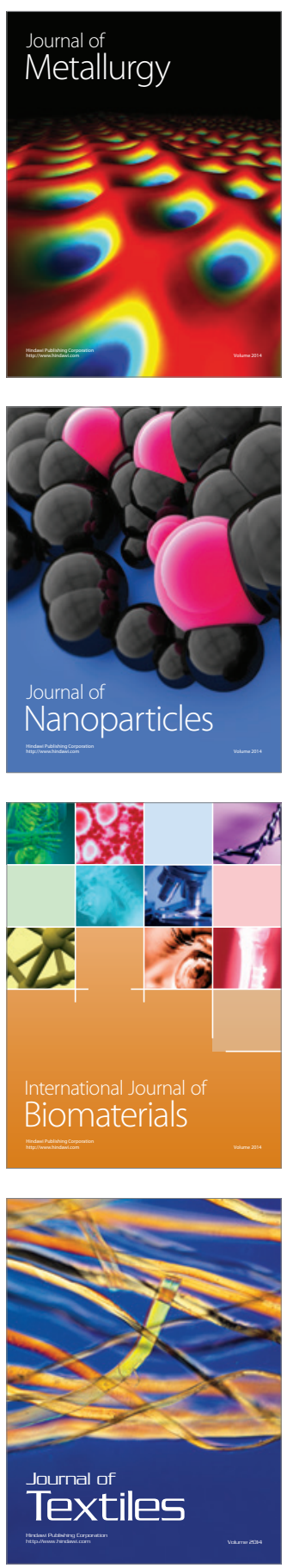